\title{
Decomposition of Egeria densa Planchon (Hydrocharitaceae) in a well oxygenated tropical aquatic ecosystem
}

\author{
Marina S. SUZUKI, ${ }^{*}$ Mateus N. FONSECA, ${ }^{2}$ Bruno S. ESTEVES, ${ }^{2}$ Gustavo G. CHAGAS ${ }^{2}$ \\ ${ }^{1}$ Laboratório de Ciências Ambientais, Universidade Estadual do Norte Fluminense Darcy Ribeiro, Av. Alberto Lamego 2000, Parque \\ Califórnia, Campos dos Goytacazes, RJ, Brazil; ${ }^{2}$ Programa de Pós-Graduação em Ecologia e Recursos Naturais, Universidade Estad- \\ ual do Norte Fluminense Darcy Ribeiro, Campos dos Goytacazes, RJ, Brazil
}

\begin{abstract}
The aims of this study were to evaluate the decomposition rate $\left(K_{T}\right)$ of the submerged aquatic macrophyte Egeria densa Planchon and measure the associated nutrients release, using both qualitative and quantitative methods. Additionally, we compared the effects of microorganisms alone versus microorganisms plus invertebrates on the decomposition process. The experiment was performed using two mesh litter bags (45 $\mu \mathrm{m}$ for microbial activity only and $2 \mathrm{~mm}$ for microbial and invertebrate activity) during two distinct periods: the dry season, September to November of 2003, and the rainy season, January to February of 2004 in the Campelo Lake (Northern of Rio de Janeiro State, Brazil). The $K_{T S}$, calculated using a single exponential model, were higher in the $45 \mu m$ mesh bags in the dry season and in the $2 \mathrm{~mm}$ mesh in the rainy season (dry $K_{T}: 45 \mu \mathrm{m}=0.0384,2 \mathrm{~mm}=0.0355$; rainy $K_{T}: 45 \mu \mathrm{m}=0.0483,2 \mathrm{~mm}=0.0666$ ), when higher temperatures (rainy season $\sim 30^{\circ} \mathrm{C}$; dry season $\sim 25^{\circ} \mathrm{C}$ ) were observed. The half-life of the E. densa detritus ranged from 14 to 27 days. The action of microorganisms was the main process causing the decomposition of $\mathrm{E}$. densa in the Campelo Lake, as shown by the decomposition rate of the $45 \mu \mathrm{m}$ mesh bags. However, invertebrates were important for the fragmentation, catabolism and leaching processes within the detritus contained in the $2 \mathrm{~mm}$ litter bags, accelerating its degradation, especially during the rainy season. The accelerated loss of chemical compounds such as nitrogen, carbon and phosphorus in the remaining detritus throughout the decomposition process stresses the importance of the decomposition process for the rapid nutrient cycling in the Campelo Lake and for the maintenance of high primary productivity.
\end{abstract}

Key words: Submerged macrophyte, litter bags, nutrient cycle, shallow lake.

Received: May 2014. Accepted: October 2014.

\section{INTRODUCTION}

In the Neotropics, there is a great diversity of aquatic environments characterized by their shallowness, which facilitates colonization by aquatic macrophytes (Esteves, 2011). In these systems, aquatic macrophytes play an important role in the ecosystem dynamics because they have high biomass production and because they are the most abundant sources of organic matter. In these well vegetated shallow water bodies, macrophyte decomposition represents the main nutrients cycling mechanism (Scheffer, 2001; Shilla et al., 2006), releasing nutrients for the primary producers (Battle and Mihuc, 2000; Xie et al., 2004).

This process generally has two distinct phases (Esteves and Barbieri, 1983; Silver and Miya, 2001). First, the physical processes of leaching and cellular lysis occur, releasing the nonstructural soluble fractions, such as carbohydrates, proteins, phosphate and potassium (Bastardo, 1981). During this phase, invertebrates are the main supporters of the fragmentation processes (Bianchini Jr., 2003). During the second phase of degradation, biological processes are dominant as a consequence of the catabolic action of detritivorous organisms. These organisms promote partial or total breakdown of the particulate organic matter (POM), especially by enzymatic activity (Vrba et al., 2004). This second phase is slower than the first, especially in presence of detritus which is rich in refractory structural compounds (Bianchini Jr., 2003).

The submerged aquatic macrophyte Egeria densa Planchon grows by forming extensive stands, especially in alkaline environments (Bini and Thomaz, 2005); it is the dominant primary producer in the Campelo Lake (Northern of Rio de Janeiro State, Brazil) and directly affects nutrient cycling in the lake. This macrophyte is reported to have low lignocellulosic fiber content (Nunes et al., 2011), resulting in an accelerated breakdown rate of the detritus.

The present study aimed to i) evaluate the decomposition process of $E$. densa in the Campelo Lake; and ii) infer the importance of this process for the nutrient release to the water column. The rate of the decay process resulting from microbial degradation was compared with decomposition rates that included additional exposure to invertebrate organisms, using litter bags of two different mesh sizes $(45 \mu \mathrm{m}$ and $2 \mathrm{~mm})$. We hypothesized that the process mediated by microorganisms alone ( $45 \mu \mathrm{m}$ mesh) would not be slower than that mediated by microorganisms plus invertebrates ( $2 \mathrm{~mm}$ mesh), due to the labile composition of detritus. Moreover, the experiments were conducted during two seasons: a dry season (September 
to November 2003) and a rainy season (January to February 2004) to verify the existence of seasonality in the E. densa decomposition process.

\section{METHODS}

\section{Study area}

Campelo Lake is one of the three largest lakes of the northern region of the Rio de Janeiro State $\left(41^{\circ} 11^{\prime} \mathrm{W}\right.$ $\left.21^{\circ} 39^{\prime} \mathrm{S}\right)$, Brazil. It is located between the municipalities of Campos dos Goytacazes and São Francisco do Itabapoana. It is geologically based on quaternary fluviomarine sediments that form the delta of the Paraíba do Sul River (Fig. 1). This lake is a typical tropical shallow lake (mean depth $\sim 1.0 \mathrm{~m}$ ). The lake is submitted to constant, predominantly northern winds, which are responsible for the maintenance of sediment resuspension. The surface area, approximately $12 \mathrm{~km}^{2}$, is extensively colonized by the aquatic macrophyte Typha domingensis Pers. in the littoral zone and by mixed or monospecific stands of submersed aquatic macrophyte such as E. densa and Ceratophyllum demersum L. that occupy the majority of the limnetic zone. Additionally, high production of phytoplanktonic biomass, dominated by cyanobacteria, was observed throughout the years, always at concentrations above $10 \mu \mathrm{g}$ Chl- $a \mathrm{~L}^{-1}$ (Suzuki, unpublished data).

\section{Decomposition experiment}

Five grams of $E$. densa previously collected at the Campelo Lake were used in the experiments. The material was dried in an oven with forced air circulation at $40^{\circ} \mathrm{C}$. The samples were packed into litter bags with one of two mesh sizes ( $45 \mu \mathrm{m}$ and $2 \mathrm{~mm}$ ). For each season and mesh size, 33 litter bags were used, composing a total of 132 litter bags.

At a site located in Campelo Lake (Fig. 1), experiments were performed during two distinct seasons: dry (September to November 2003) and rainy (January to February 2004). The experimentation site was marked by buoys. The litter bags were tied to a rope that kept them at $50 \mathrm{~cm}$ deep in the water column. This depth was sufficiently near the sediment $(80 \mathrm{~cm}$ depth in the experimental site) to allow invertebrate colonization and yet prevented burial of the litter bags in the sediment; the sediment was constantly resuspended by the wind. Three samples of each type of litter bag were collected periodically at 1, 3, 7, 14 days, and then weekly until the material was almost completely degraded. During the dry season, the litter bags were set out on September 16 $6^{\text {th }}, 2003$ and the experiment was terminated after 56 days; during the rainy season, the experiment started on January $7^{\text {th }}, 2004$ and was terminated after 35 days as a consequence of the quicker degradation.

The recovered material was dried in an oven with forced air circulation at $40^{\circ} \mathrm{C}$ until the weight became constant to quantify the loss of mass, and ground. There was little material remaining material in the last set of samples for both mesh sizes of litter bags from the dry season and in the last set of samples of $2 \mathrm{~mm}$ litter bags from the rainy season; bulked samples were therefore

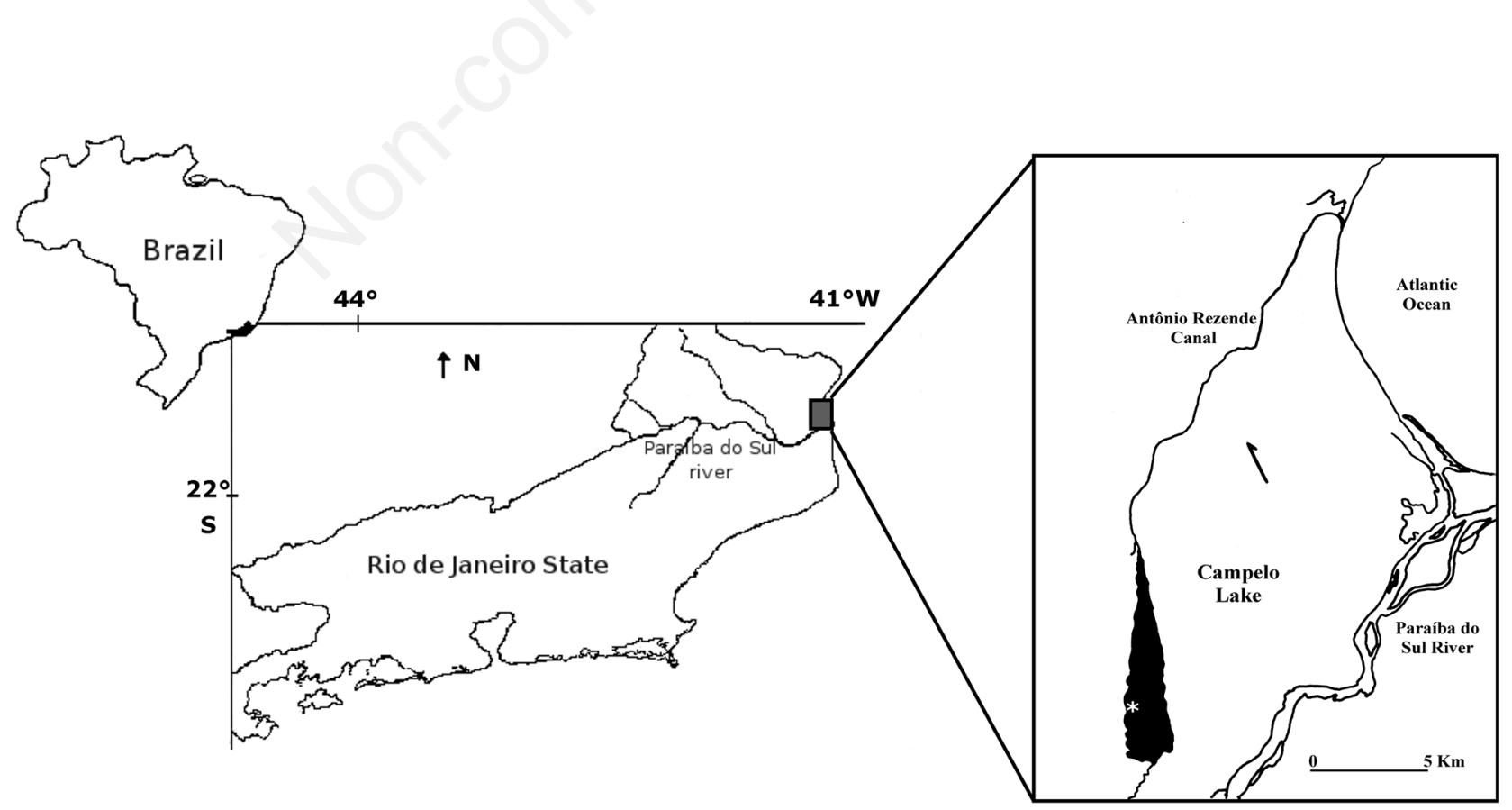

Fig. 1. Representation of the State of Rio de Janeiro, Brazil, highlighting the Campelo Lake location. Experimentation site is marked by white asterisk in the lake. 
used. The decomposition rate was calculated using the data from the loss of weight within a negative exponential model (Olson, 1963; Wieder and Lang, 1982):

$\mathrm{Wt}=\mathrm{W}_{0} \mathrm{e}^{-\mathrm{kt}}$

where

$\mathrm{Wt}=$ remaining weight of the detritus as a function of time $\mathrm{t}$; $\mathrm{W}_{0}=$ initial weight;

$\mathrm{K}=$ decomposition rate $\left(\right.$ day $\left.^{-1}\right)$.

The half-life of the detritus was calculated using the formula proposed by Olson (1963): $\mathrm{T}_{50}=0.963 / \mathrm{K}$.

Data on the water temperature and dissolved oxygen (DO) were taken with a portable Oximeter (YSI 55; YSI Inc., Yellow Springs, OH, USA) on each sampling date. The results from these variables were expressed as the average of the dry and rainy seasons.

The total phosphorus $(\mathrm{P})$ content in plant materials was determined by colorimetric analysis (Molybdenum blue; Pompêo and Moschini-Carlos, 2003), using two representative samples from each sampling day in triplicates. Due to the small amount of dry material available, it was not possible to determine total $P$ for the last few last sampling days of the rainy season (from the $14^{\text {th }}$ day in $2 \mathrm{~mm}$ and from the $26^{\text {th }}$ day in $45 \mu \mathrm{m}$ mesh). The determinations of organic carbon $(\mathrm{C})$ and nitrogen $(\mathrm{N})$ contents were made through combustion by a CHN/S Perkin Elmer 2400 analyzer using pooled samples.

To compare the data obtained for both treatments and between seasons, two statistical tests were performed. A $t$ test for samples with unequal variances was used to compare the proportion of mass lost in the two different mesh sizes treatments ( $45 \mu \mathrm{m}$ and $2 \mathrm{~mm}$ ), considering each sampling days separately. The adjustment and the standard error of the exponential model was performed in the program $\mathrm{R}$ to test the null hypothesis that the decomposition rates for the two meshes were not significantly different $(\alpha=0.05)$.

\section{RESULTS}

\section{Decomposition rates}

The decomposition rates and the parameters obtained for the adjustment of the exponential model and the halflife of $E$. densa detritus are presented in Tab. 1. Decomposition rates obtained during the dry season showed slightly higher values $(8 \%)$ when invertebrates was excluded (45 $\mu \mathrm{m}$ mesh) in relation to $2 \mathrm{~mm}$ mesh. However, the $\mathrm{K}_{\mathrm{T}}{ }^{-1}$ for the $45 \mu \mathrm{m}$ mesh was $25 \%$ lower than the litter bags that included action by invertebrates $(2 \mathrm{~mm}$ mesh) during the rainy season, when the water temperatures were higher (29.0 $0.9^{\circ} \mathrm{C}$ compared to $24.6 \pm 1.5^{\circ} \mathrm{C}$ during the dry season). Thus, only during the rainy season did the adjustment of exponential model generate a significant difference $(\mathrm{P}<0.001)$ between the decomposition rates of detritus inside $45 \mu \mathrm{m}$ and $2 \mathrm{~mm}$ meshes litter bags (Fig. 2b). The loss of detrital material in the $45 \mu \mathrm{m}$ and $2 \mathrm{~mm}$ bags showed significant differences only on the $3^{\text {rd }}, 7^{\text {th }}$ and $49^{\text {th }}$ days during the dry season (Fig. 2a) and from the $26^{\text {th }}$ day onward during the rainy season. Further, Fig. 2 shows that the decomposition process is faster in the beginning, resulting in a substantial weight loss in the detritus for both treatments and seasons (up to $15 \%$ after one day and up to $30 \%$ in a week). The detritus in the $45 \mu \mathrm{m}$ mesh showed a half-life of 25 days during the dry season and 20 days during the rainy season. In the $2 \mathrm{~mm}$ mesh, the detritus showed a halflife of 27 days during the dry season and 14 days during the rainy season.

\section{Release and accumulation of carbon, nitrogen and phosphorus and the $\mathrm{C}: \mathrm{N}$ ratio}

Initial concentrations of detrital material were 360.1, 8.1 and $3.5 \mathrm{mg} \mathrm{g}^{-1}$ of dry weight (DW) of C, N and P, respectively.

The remaining $\mathrm{C}$ percentage in the litter bags showed similar decay patterns for mass loss for both mesh sizes

Tab. 1. Decomposition coefficients $\mathrm{K}_{\mathrm{T}}^{-1}\left(\right.$ day $\left.^{-1}\right)$; standard error, degree of freedom and correlation coefficient $\left(\mathrm{R}^{2}\right)$ of exponential model, and half-life $\left(\mathrm{T}_{50}\right)$ of detritus of Egeria densa in the $45 \mu \mathrm{m}$ and $2 \mathrm{~mm}$ mesh sizes in the dry (from September to November 2003) and rainy (from January to February 2004) seasons.

\begin{tabular}{|c|c|c|c|c|c|}
\hline Mesh & $\begin{array}{c}\mathbf{K}_{\mathrm{T}}^{-1} \\
\left(\mathrm{day}^{-1}\right)\end{array}$ & SE & df & $\mathbf{R}^{2}$ & $\begin{array}{c}\mathrm{T}_{50} \\
\text { (days) }\end{array}$ \\
\hline \multicolumn{6}{|c|}{ Dry season } \\
\hline $45 \mu \mathrm{m}$ & 0.0384 & 0.0017 & 29 & 0.9663 & 25 \\
\hline $2 \mathrm{~mm}$ & 0.0355 & 0.0022 & 29 & 0.9410 & 27 \\
\hline \multicolumn{6}{|c|}{ Rainy season } \\
\hline $45 \mu \mathrm{m}$ & 0.0483 & 0.0021 & 20 & 0.9793 & 20 \\
\hline $2 \mathrm{~mm}$ & 0.0666 & 0.0041 & 32 & 0.9573 & 14 \\
\hline
\end{tabular}

$S E$, standard error; $d f$, degree of freedom. 
(45 $\mu \mathrm{m}$ and $2 \mathrm{~mm}$ ) and both seasons (Fig. 3 a,b). The decay was faster at the beginning of the decomposition process, especially in the rainy season. Regarding the $\mathrm{N}$ content, it was possible to identify a pattern, accentuated in the rainy season, of an initial increase in the remaining material followed by decline over the last days of the decomposition, especially in the $2 \mathrm{~mm}$ mesh bags. The lowest variation in remaining $\mathrm{N}$ content was observed in the $45 \mu \mathrm{m}$ mesh during the dry season: from $133 \%$ to $82 \%$. The highest was recorded for the $2 \mathrm{~mm}$ mesh during the rainy season, when the $\mathrm{N}$ content ranged from $227 \%$ to $5 \%$ of the initial value. Additionally, the lowest remaining percentage of $\mathrm{N}$ in the $45 \mu \mathrm{m}$ mesh litter bags did not exceed $75 \%$ during either season, while the decline in the remaining $\mathrm{N}$ content in the $2 \mathrm{~mm}$ mesh was apparent (Fig. $3 \mathrm{c}, \mathrm{d})$. The $\mathrm{P}$ content in the remaining detritus exhibited a sharp decline in both mesh sizes $(45 \mu \mathrm{m}$ and $2 \mathrm{~mm})$ during the two studied seasons. After one day of decomposition, $62-75 \%$ of the initial $\mathrm{P}$ was leached. Subsequently, a slow decrease in the remaining $\mathrm{P}$ content was observed. By the $49^{\text {th }}$ day only $3 \%$ of initial $\mathrm{P}$ content remained in 2 $\mathrm{mm}$ mesh during the dry season. The same tendency was observed during the rainy season while sufficient material remained for analysis (Fig. 3 e,f). The $\mathrm{C}: \mathrm{N}$ ratio (Fig. 4) decreased during the decomposition process, especially in the $45 \mu \mathrm{m}$ mesh. An exception occurred for the $2 \mathrm{~mm}$ mesh bags during the rainy season; from the $20^{\text {th }}$ day, an increase in $\mathrm{C}: \mathrm{N}$ ratio was observed, reaching a value of $36: 1$ in the sample on the last day. The initial samples in the litter bags exhibited ratios near to 50:1. During the rainy season, the $\mathrm{C}: \mathrm{N}$ ratios decreased quickly within both meshes throughout the experiment, corresponding to the increase of $\mathrm{N}$ content.

\section{DISCUSSION}

The decomposition rates of the detritus of E. densa in the $45 \mu \mathrm{m}$ and in the $2 \mathrm{~mm}$ mesh litter bags did not show a significant difference during the dry season. This result suggests that leaching and microorganisms were responsible for the majority of the detritus decay. During the rainy season, weight loss differences were recorded only from the 26th day onward. The $2 \mathrm{~mm}$ mesh size facilitates the action of macro- and meso-invertebrates, which accelerates fragmentation, catabolism and leaching (Danell and Sjöberg, 1979; Brock et al., 1985; Neely, 1994). The presence of macro-invertebrates on the $2 \mathrm{~mm}$ mesh was observed during the initial days of experimentation in both seasons. These results partially supports our hypothesis that the process mediated exclusively by microorganisms is not slower in comparison to that mediated by microorganisms plus invertebrates. Under our experimental conditions, the results indicate that the activity of invertebrates is not essential to increase the decomposition rate for $E$. densa. This result is in contrast to the findings in other studies with similar macrophytes (Battle and Mihuc, 2000; Pompêo and Moschini-Carlos, 2003).

The degradation of organic matter is driven by several factors, such as water temperature, concentration of dissolved nutrients in water, the chemical composition of the a

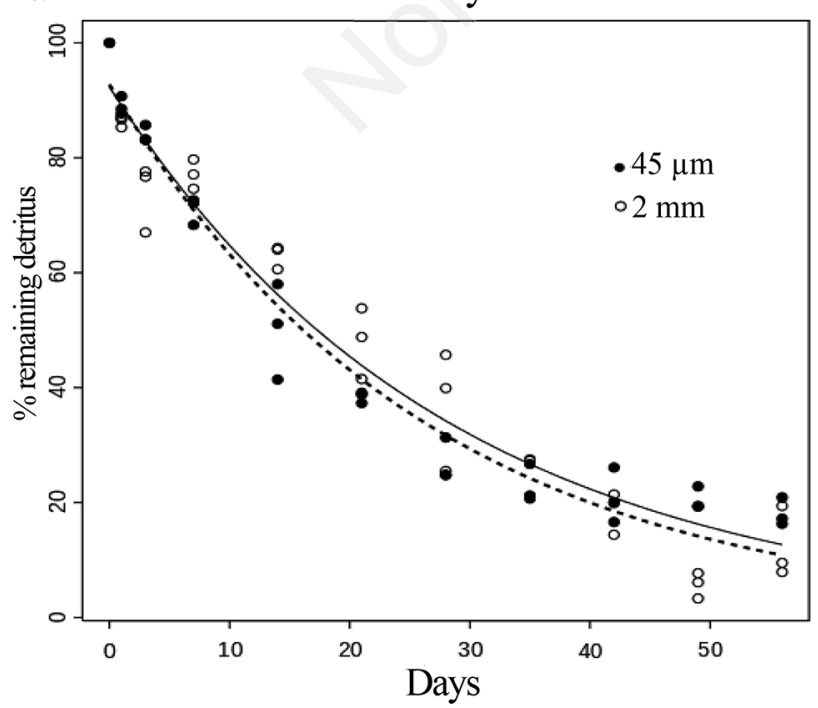

b

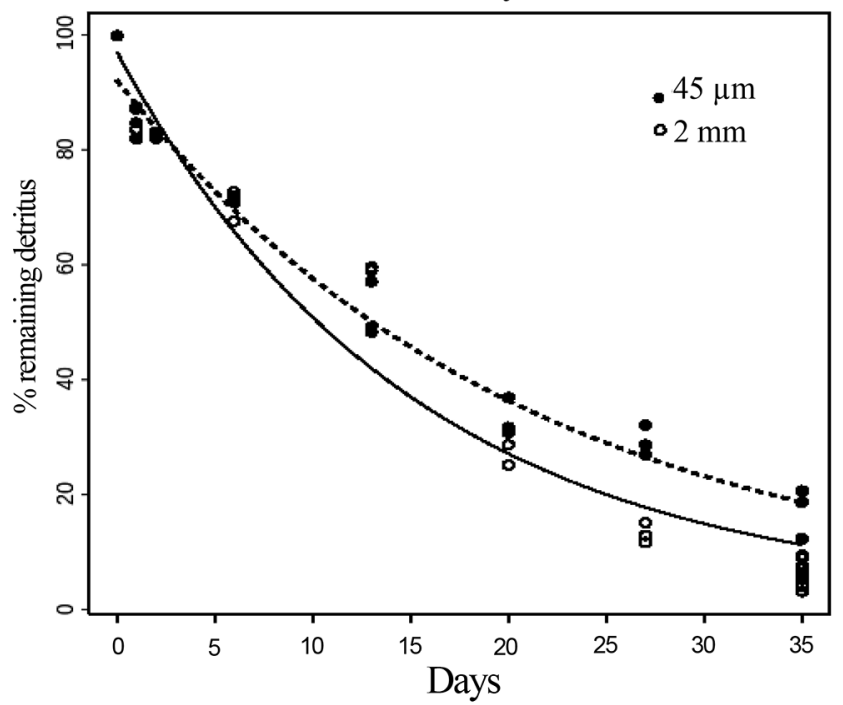

Fig. 2. Percentage of the material remaining within litter bags with $2 \mathrm{~mm}$ and $45 \mu \mathrm{m}$ mesh sizes in the dry (from September to November 2003) and rainy (from January to February 2004) seasons. 
detritus (Pompêo and Moschini-Carlos, 2003; Li et al., 2012), availability of oxygen in water (Cunha-Santino and Bianchini Jr., 2002) and composition of the microbial and macro-invertebrate community (Stripari and Henry, 2002; Goncalves Jr. et al., 2004). Environments dominated by macrophytes provide an organic substrate able to sustain a productive microbial community (Schlickeisen et al., 2003 ) well adapted to local conditions. Hackney et al. (2000), Gulis and Suberkropp (2003), Mille-Lindblom and Tranvik (2003), and Sampaio et al. (2007) among others, have largely highlighted the microbial contribution to the detritus weight loss. The microbial community plays a key role in the flow of matter and energy of the aquatic ecosystem. In addition to acting in the degradation of or- ganic matter, they are responsible for the condition of detritus, promoting their consumption by aquatic invertebrates (Findlay, 2010). The decomposition rates obtained in this study corroborate that temperature can be a dominant physical factor of this process (Howard-Williams and Davis, 1979; Janssen and Walker, 1999; Chimney and Pietro, 2006), because the decomposition was approximately 1.3 and 1.8 times faster during the warmer period (for the $45 \mu \mathrm{m}$ and $2 \mathrm{~mm}$ meshes, respectively). This may be because higher temperatures accelerate the microorganism's metabolism (Moran and Hodson, 1989; Carvalho et al., 2005).

Among the other factors that influence decomposition, the absence of a sustaining rigid cellular structure, the low
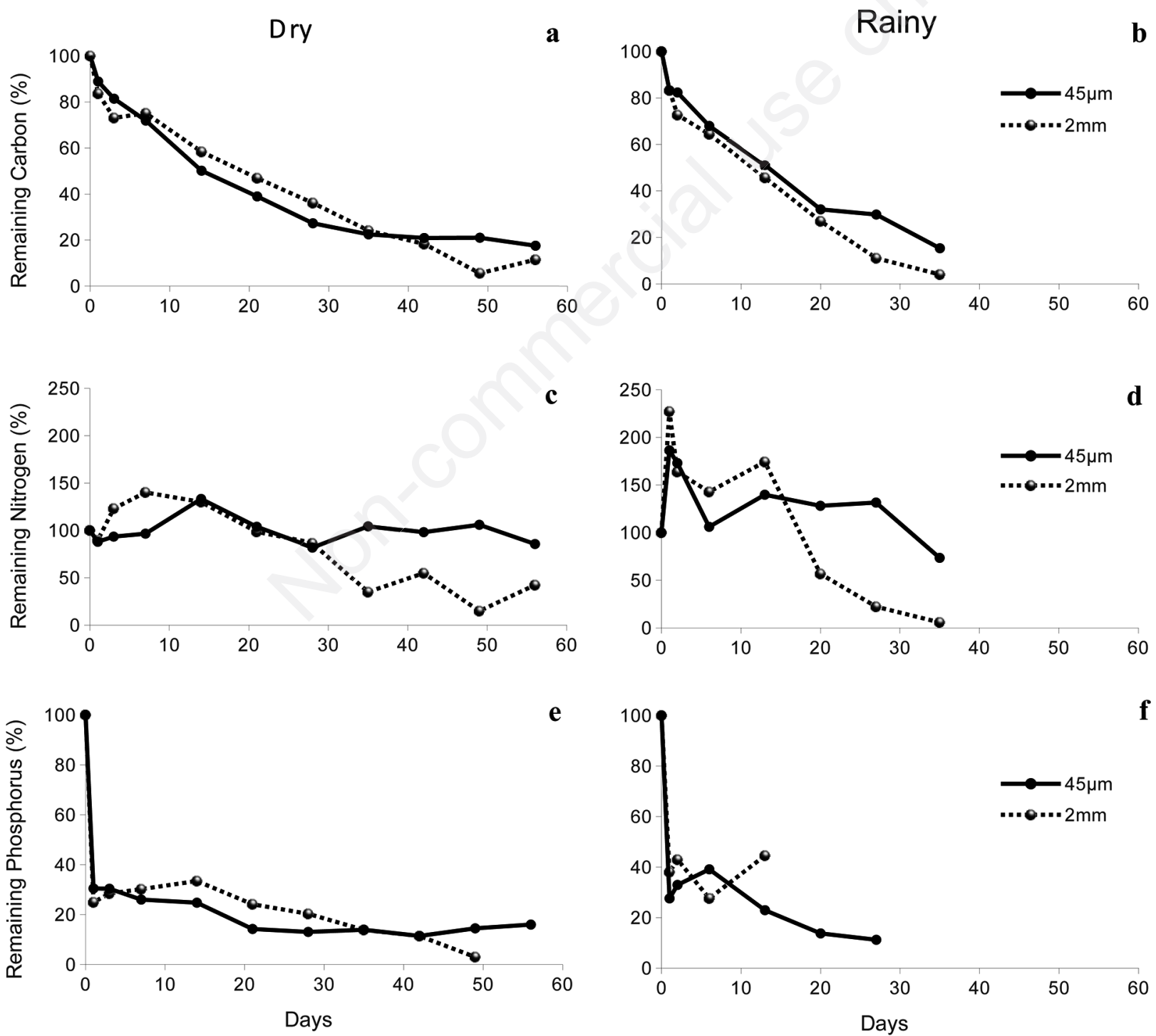

Fig. 3. Percentage of the remaining carbon (a, b), nitrogen (c, d) and phosphorus (e, f) from the 2 mm and $45 \mu \mathrm{m}$ mesh sized litter bags for the dry (from September to November 2003) and rainy (from January to February 2004) seasons. 
fiber and silica contents (Chimney and Pietro, 2006) and the high initial nutrient content of the detritus can explain the similar velocity observed in the decomposition rates at our two experimental conditions $(45 \mu \mathrm{m}$ and $2 \mathrm{~mm}$ mesh litter bags). According to Esteves (2004), specimens of $E$. densa collected in the Campelo Lake contained approximately $5 \mathrm{mgP} \mathrm{g}^{-1}, 150 \mathrm{mgProtein} \mathrm{g}^{-1}$ and $110 \mathrm{mgCH} \mathrm{g}^{-1}$ DW. Proteins and carbohidrates accounted for approximately $25 \%$ of their organic matter content. Compounds as $\mathrm{P}$, proteins and carbohidrates are readily leached during the first stage of degradation. E. densa and similar submerged species do not require rigid cells as supportive structure and present lower concentrations of compounds such as lignin and cellulose. Consequently, the lower concentrations of refractory fibers help to accelerate the degradation process. Additionally, several environmental conditions of the Campelo Lake may explain the notably high degradation of detritus observed. The decomposition of aquatic macrophytes may have been accelerated by the availability of nutrients in the water column that might be used by the decomposers (Valiela et al., 1985; Rejmánková and Houdkova, 2006). Data not published indicate the Campelo Lake as a meso-eutrophic system, with orthophosphate concentrations above $0.4 \mu \mathrm{M}$ and inorganic dissolved $\mathrm{N}$ above $4 \mu \mathrm{M}$. In general, the aerobic mineralization is faster, resulting in more stable final products (e.g., carbon dioxide, water; Wetzel, 1995) and tending to transfer more carbon to the growth of microorganisms (Davis and Cornwell, 1991). Therefore, the high saturation of DO observed during the experiments in the Campelo Lake ( $102 \pm 22 \%$ in the dry season; $72 \pm 8.5 \%$ in the rainy season) may have favoured the microbial growth.

The mean half-life values obtained for $E$. densa in our experiments were shorter than those observed for other macrophytes (Battle and Mihuc, 2000; Xie et al., 2004; Carvalho et al., 2005; Chimney and Pietro, 2006). These values could be explained by the high radiance at the stud-

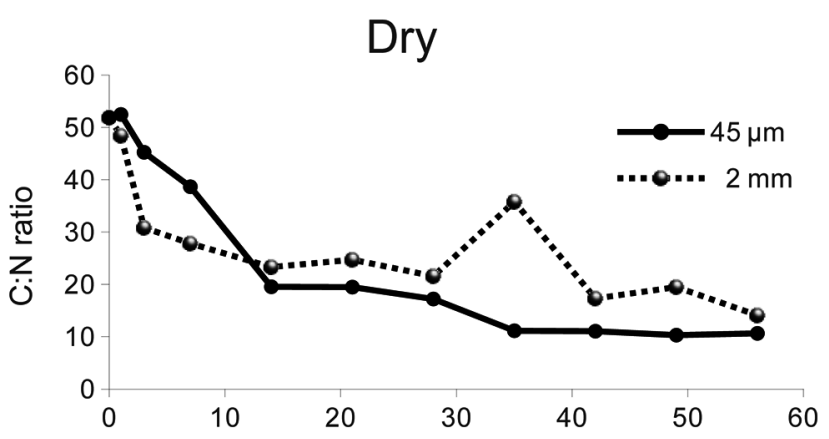

ied region, resulting in higher temperatures, the high saturation of dissolved oxygen, the high quality of the nutritional composition of the substrate and the high availability of nutrients in the water column.

The increase on the $\mathrm{N}$ content of the detritus suggests that quick association of bacteria to the detritus occurs (Boyd, 1970; Pagioro and Thomaz, 1999), mainly during the rainy season. According to Iversen (1973), these bacteria have high $\mathrm{N}$ content and $\mathrm{N}$ rich compounds. Yet the increase in the $\mathrm{N}$ content could be explained by the adsorption of inorganic $\mathrm{N}$ compounds onto the surface of the detritus (Pagioro and Thomaz, 1999). This pattern has been observed in many decomposition experiments (Esteves and Barbieri, 1983; Brock, 1984; Poi de Neiff and Neiff, 1988; Gessner, 2000; Villar et al., 2001). This enrichment of $\mathrm{N}$ results in both a decrease of the $\mathrm{C}: \mathrm{N}$ ratio and an increase of the nutritional value of the detritic material, which increases the degradation velocity (Iversen, 1973; Poi de Neiff and Neiff, 1988). In contrast, P levels in this study decreased during both seasons from the first day of the experiments, concurring with similar reports by Roland et al. (1990), Pagioro and Thomaz (1998), and Villar et al. (2001). As a great part of the total fraction of $P$ in aquatic macrophytes is represented by soluble compounds, the leaching coefficient of $\mathrm{P}$ was calculated as 1.2 day $^{-1}$, indicating that the P half-life is less than one day. In aquatic ecosystems with high macrophyte biomass, the P release during decomposition can be considered a significant autochthonous source of nutrients (Carpenter, 1980; Wetzel 1983, 1990). An increase in $P$ concentrations in the detritus was observed in the final phase of the decomposition process, suggesting that the incrustation by periphyton elevates the concentration of this element (Brum and Esteves, 2001a, 2001b), increasing the quality of the detritus. Alternatively, the aggregation of the allocthonous inorganic material may be responsible for the additional P in the detritus (Esteves and Barbieri, 1983).

Fig. 4. $\mathrm{C}: \mathrm{N}$ molar ratios in the detritus remaining in the $2 \mathrm{~mm}$ and $45 \mu \mathrm{m}$ mesh sizes in the dry (from September to November 2003) and rainy (from January to February 2004) seasons. 
The high decomposition rate and fast degradation process of $E$. densa may result in the quick release of nutrients to the water column. This release may contribute to the high primary production rates (Suzuki et al., unpublished data) observed at the Campelo Lake.

\section{CONCLUSIONS}

The present results ratified that the aquatic macrophyte $E$. densa exhibits high decomposition rates, especially during the rainy season when water temperatures were higher. Due to the low content of refractory compounds, the role of invertebrates for the decomposition process of $E$. densa is not essential. The variations on the content of $\mathrm{C}, \mathrm{N}$, and $\mathrm{P}$ emphasize the great importance of the decomposition process of this species for nutrient cycling and for the availability of those nutrients to primary producers in colonized habitats.

\section{ACKNOWLEDGMENTS}

The authors are greatly thankful to Antônio Carlos de Oliveira Pessanha for invaluable help in field work, to Giselle Freesz for contributions to analytical aspects and to anonymous advisors that contributed to the improvement of the paper. This work was partially supported by CNPq INCT-TMCOcean (Proc. 573.601/08-9).

\section{REFERENCES}

Bastardo H, 1981. [Actividad microbiana durante la decomposición de gramineas tropicales en sabanas inundables]. [Article in Spanish]. Acta Biol. Venez. 11:149-168.

Battle JM, Mihuc TB, 2000. Decomposition dynamics of aquatic macrophytes in the lower Atchafalaya, a large floodplain river. Hydrobiologia 418:123-136.

Bianchini Jr. I, 2003. [Modelos de crescimento e decomposição de macrófitas aquáticas, p. 85-126]. In: S.M. Thomaz and L.M. Bini (eds.), Ecologia e manejo de macrófitas aquáticas]. [Book in Portuguese]. UEM, Maringá.

Bini LM, Thomaz SM, 2005. Prediction of Egeria najas and Egeria densa occurrence in a large subtropical reservoir (Itaipu Reservoir, Brazil-Paraguay). Aquat. Bot. 83:227-238.

Boyd CE, 1970. Losses of mineral nutrients during decomposition of Typha latifolia. Arch. Hydrobiol. 66:511-517.

Brock TCM, 1984. Aspects of the decomposition of Nymphoides Peltata (Gmel.) O. Kuntze (Menyanthaceae). Aquat. Bot. 19: 131-156.

Brock TCM, DeLyon MJH, Van Laar EMJM, Van Loon EMM, 1985. Field studies on the breakdown of Nuphar lutea (L.) SM. (Nymphaeaceae), and a comparison of three mathematical models for organic weight loss. Aquat. Bot. 21:1-22.

Brum PR, Esteves FA, 2001a. Dry weight loss and chemical changes in the detritus of three tropical aquatic macrophyte species (Eleocharis interstincta, Nymphaea ampla and Potamogenton stenostachys) during decomposition. Acta Limnol. Bras. 13: 61-73.

Brum PR, Esteves FA, 2001b. Changes in abundance and biomass of the attached bacterial community throughout the de- composition of three species of aquatic macrophytes. Oecol. Bras. 9: 77-96.

Carvalho P, Thomaz SM, Bini LM, 2005. Effects of temperature on decomposition of a potential nuisance species: the submerged aquatic macrophyte Egeria najas Planchon (Hydrocharitacea). Braz. J. Biol. 65:51-60.

Chimney MJ, Pietro KC, 2006. Decomposition of macrophyte litter in a subtropical constructed wetland in South Florida (USA). Ecol. Engeneering 4:301-321.

Cunha-Santino MB, Bianchini Jr I, 2002. [Estequiometria da decomposição aeróbia de galhos, cascas, serrapilheira e folhas, p. 185-197]. In: E. Espíndola (ed.) Recursos hidroenergéticos: usos, impactos e planejamento integrado de São Carlos].[Book in Portuguese]. RiMa.

Danell K, Sjöberg K, 1979. Decomposition of Carex and Equisetum in a northern Swedish lake: dry weight loss and colonization by macro-invertebrates. J. Ecol. 67:191-200.

Davis ML, Cornwell DA, 1991. Introduction to environmental engineering. New York, Mc Graw-Hill: 822 pp.

Esteves BS, 2004. [Composição nutricional de macroalgas e macrófitas aquáticas em duas lagoas costeiras do Norte Fluminense]. [PhD Thesis in Portuguese]. UENF, Campos dos Goytacazes, Brazil.

Esteves FA, 2011. [Fundamentos em Limnologia. 3].[Book in Portuguese]. Interciência - FINEP: 602 pp.

Esteves FA, Barbieri R, 1983. Dry weight and chemical changes during decomposition of tropical aquatic macrophytes in Lobo Reservoir, SP, Brasil. Aquat. Bot. 16:285-295.

Findlay S, 2010. Stream microbial ecology. J. N. Am. Benth. Soc. 29:170-181.

Gessner MO, 2000. Breakdown and nutrient dynamics of submerged Phragmites shoots in the littoral zone of a temperate hardwater lake. Aquat. Bot. 66:9-20.

Gonçalves Jr. JF, Santos AM, Esteves FA, 2004. The influence of the chemical composition of Typha domingensis and Nymphaea ampla detritus on invertebrate colonization during decomposition in a brazilian coastal lagoon. Hydrobiologia 527:125-137.

Gulis V, Suberkropp K, 2003. Effect of inorganic nutrients on relative contributions of fungi and bacteria to carbon flow from submerged decomposing leaf litter. Microbial Ecol. 45:11-19.

Hackney CT, Padgett DE, Posey MH, 2000. Fungal and bacterial contribution to the decomposition of Cladium and Typha leaves in nutrient enriched and nutrient poor areas of the Everglades, with a note on ergosterol concentrations in Everglades soils. Mycol. Res. 104:666-670.

Howard-Williams C, Davies BR, 1979. The rates of dry matter and nutrient loss from decomposition Potamogenton pectinatus in a brackish south-temperate coastal lake. Freshwater Biol. 9:13-21.

Iversen TM, 1973. Decomposition of autumn-shed beech leaves in a springbrook and its significance for the fauna. Arch. Hydrobiol. 72:305-312.

Janssen MA, Walker KF, 1999. Processing of riparian and wetland plant litter in the River Murray, South Australia. Hydrobiologia 411:53-64.

Li X, Cui B, Yang Q, Tian H, Lan Y, Wang T, Zhen H, 2012. Detritus quality controls macrophyte decomposition under different nutrient concentrations in a eutrophic shallow lake, north China. PLoS ONE 7:e42042. 
Mille-Lindblom C, Tranvik LJ, 2003. Antagonism between bacteria and fungi on decomposing aquatic plant litter. Microbial Ecol. 45:173-182.

Moran MA, Hodson RE, 1989. Bacterial secondary production on vascular plant detritus: relationship to detritus composition and degradation rate. Appl. Environ. Microbiol. 55:2178-2189.

Neely RK, 1994. Evidence for positive interactions between epiphytic algae and heterotrophic decomposers during the decomposition of Typha latifolia. Arch. Hydrobiol. 129:443-457.

Nunes MF, Cunha-Santino MB, Bianchini Jr. I, 2011. Xylanase and cellulase activities during anaerobic decomposition of three aquatic macrophytes. Braz. J. Microbiol. 42:75-83.

Olson JS, 1963. Energy storage and the balance of producers and decomposers in ecological systems. Ecology 44:322-331.

Pagioro TA, Thomaz SM, 1998. Loss weight and concentration of carbon, nitrogen and phosphorus during decomposition of Eichhornia azurea in the floodplain of the upper Paraná river, Brazil. Rev. Brasil. Biol. 58: 603-608.

Pagioro TA, Thomaz SM, 1999. Decomposition of Eichhornia azurea from limnologically different environments of the upper Paraná river floodplain. Hydrobiologia 411:45-51.

Poi de Neiff A, Neiff JJ, 1988. Decomposition of Eichhornia crassipes Solms in a pond of Parana River valley and colonization by invertebrates. Trop. Ecol. 29:79-85.

Pompêo ML, Moschini-Carlos V, 2003. [Macrófitas aquáticas e perifíton, aspectos ecológicos e metodológicos].[Book in Portuguese]. RiMa: 134 pp.

Rejmánková E, Howdková K, 2006. Wetland plant decomposition under different nutrient conditions: what is more important, litter quality or site quality? Biogeochem. 80:245-262.

Roland F, Esteves FA, Santos JF, 1990. [Decomposição da macrófita aquática Eichhornia azurea (Kunth.), com ênfase na colonização por bactérias epifíticas]. [Article in Portuguese]. Acta Limnol. Brasil. 3:653-673.

Sampaio A, Sampaio JP, Leao C, 2007. Dynamics of yeast populations recovered from decaying leaves in a non polluted stream: a 2-year study on the effects of leaf litter type and decomposition time. FEMS Yeast Res. 7:595-603.
Scheffer M, 2001. Ecology of shallow lakes. Kluwer: 357 pp.

Schlickeisen E, Tietjen TE, Arsuffi TL, Groeger AW, 2003. Detritus processing and microbial dynamics of an aquatic macrophyte and terrestrial leaf in a thermally constant, spring-fed stream. Microbial Ecol. 45:411-418.

Shilla D, Asaeda T, Fujino T, Sanderson B, 2006. Decomposition of dominant submerged macrophytes: implications for nutrient release in Myall Lake, NSW, Australia. Wetl. Ecol. Manag. 14:427-433.

Silver WL, Miya RK, 2001. Global patterns in root decomposition: comparison of climate and litter quality effects. Oecologia 129:407-419.

Stripari N, Henry R, 2002. The invertebrate colonization during decomposition of Eichhornia azurea Kunth in A lateral lake in the mouth zone of Paranapanema River into Jurumirim Reservoir (São Paulo, Brazil). Braz. J. Biol. 62:293-310.

Valiela I, Teal JM, Allen SE, van Etten R, Goehringer D, Volkmann S, 1985. Decomposition in salt marsh ecosystems: the phases and major factors affecting disappearance of aboveground organic matter. J. Exp. Mar. Biol. Ecol. 89:29-54.

Villar CA, Cabo L, Vaithiyanathan P, Bonetto C, 2001. Litter decomposition of emergent macrophytes in a floodplain marsh of the Lower Paraná river. Aquat. Bot. 70:105-116.

Vrba J, Callieri C, Bittl T, Šimek K, Bertoni R, Filandr P, Hartman P, Hejzlar J, Macek M, Nedoma J, 2004. Are bacteria the major producers of extracellular glycolytic enzymes in aquatic environments? Int. Rev. Hydrobiol. 89:102-117.

Xie Y, Yu D, Ren B, 2004. Effects of nitrogen and phosphorus availability on the decomposition of aquatic plants. Aquat. Bot. 80:29-37.

Wetzel RG, 1983. Limnology. Saunders College Publ.: 656 pp.

Wetzel RG, 1990. Land-water interfaces: metabolic and limnological regulators. Verh. Int. Verein. Limnol. 24:6-24.

Wetzel RG, 1995. Death, detritus, and energy flow in aquatic ecosystems. Freshwater Biol. 33:83-89.

Wieder K, Lang GE, 1982. A critique of the analytical methods used in examining decomposition data obtained from litter bags. Ecology 63:1636-1642. 